\title{
GAMBARAN DIAGNOSTIK DAN PENATALAKSANAAN PASIEN PNEUMONIA ANAK RAWAT JALAN RUMAH SAKIT UMUM DR PRINGADI MEDAN
}

\author{
Ryeo Ramadhan Chairun ${ }^{1}$, Linda Chiuman ${ }^{2}$ \\ 1,2Program Studi Pendidikan Dokter, Fakultas Kedokteran, Universitas Prima Indonesia \\ ${ }^{1}$ ramadhanryeo100@gmail.com
}

\begin{abstract}
Abstrak
Penyakit infeksi pada jaringan paru ini disebut Pneumonia, Infeksi pada jaringan paru ini disebabkan oleh mikroorganisme (Bakteri,Virus, Protozoa) tetapi bukan disebabkan oleh bakteri M.Tuberculosis. Penelitian ini dilakukan bertujuan untuk dapat mengetahui Gambaran diagnostik dan penatalaksanaan pasien Pneumonia anak rawat jalan rumah sakit umum DR Pringadi Medan. Beberapa penyebab tingginya kasus pneumonia pada anak antara lain sebagai berikut : anak yang masih berumur dibawah usia 1 tahun, lakilaki,anak dengan gizi buruk,anak lahir dengan berat badan yang rendah atau sangat rendah, asupan nutrisi ASI yang tidak adekuat, polusi udara, faktor keluarga pada lingkungan anak, imunisasi yang tidak lengkap, kekurangan vitamin A, dan asupan MP-ASI yang tidak benar. Dengan menggunakan metode penelitian case study diikuti juga dengan deskriptif retrospektif penelitian ini dilakukan, pada penelitian ini sampel yang digunakan berupa 100 data rekam medis pasien diambil secara purposive sampling. Didapatkan hasil penelitian berdasarkan distribusi proporsi umur terdapat umur dibawah 1 tahun memiliki persentase teringgi pada anak yang terkena Pneumonia, dibandingkan usia 2 hingga lebih 6 tahun. Gejala klinis yang paling tampak pada anak yang terinfeksi pneumonia ialah Demam, Batuk berdahak dan sesak nafas serta pada pemeriksaan fisik berupa auskultasi persentase paling tinggi didapatkan suara nafas tambahan berupa ronkhi basah dan pemeriksaan foto thoraks menunjukkan konsolidasi paling banyak pada anak terinfeksi Pneumonia. Pada penatalaksanaan kepada anak yang terinfeksi Pneumonia diberikan Amoxilin sirup, Ambroxol sirup, Paracetamol sirup memiliki persentase tertinggi dalam kesembuhan.
\end{abstract}

Kata Kunci : Pneumonia, Diagnostik dan Penatalaksanaan, RSU Pringadi Medan.

\section{Abstract}

This infectious disease in the lung tissue is called pneumonia. This infection of the lung tissue is caused by microorganisms (Bacteria, Viruses, Protozoa) but not by M. Tuberculosis. This study was conducted to determine the diagnostic picture and management of outpatient pneumonia patients at the general hospital, DR Pringadi Medan. Some of the causes of high cases of pneumonia in children include the following: children under the age of 1 year, boys, malnourished children, children born with low or very low body weight, inadequate intake of breast milk nutrition, air pollution, family factors in the child's environment, incomplete immunization, vitamin A deficiency, and improper complementary feeding. By using a case study research method followed by a retrospective descriptive research was conducted, in this study the sample used was 100 patient medical record data taken by purposive sampling. The results of the study were based on the distribution of age proportions, there were those under 1 year of age who had the highest percentage of children with pneumonia, compared to those aged 2 to over 6 years. The most visible clinical symptoms in children infected with pneumonia are fever, cough with phlegm and shortness of breath and on physical examination, in the form of auscultation the highest percentage of additional breath sounds is wet rhonchi and chest X-ray examination shows the most consolidation in children infected with pneumonia. In the management of children infected with pneumonia, Amoxicillin syrup, Ambroxol syrup, Paracetamol syrup were given the highest percentage of the recovery.

Keywords: Pneumonia, treatment and diagnostic, RSU Pringadi Medan. 

Vol. 5/No. 3/Juli 2020; Issn: 2502-731X

\section{PENDAHULUAN}

Pneumonia dapat disebut juga infeksi pada jaringan paru yang disebabkan oleh mikroorganisme (bakteri,virus,protozoa) tetapi bukan disebabkan oleh M.Tuberculosis. Beberapa penyebab tingginya kasus pneumonia pada anak antara lain sebagai berikut : anak yang masih berumur dibawah usia 1 tahun, laki-laki,anak dengan gizi buruk,anak lahir dengan berat badan yang rendah atau sangat rendah, asupan nutrisi ASI yang tidak adekuat, polusi udara, faktor keluarga pada lingukang anak, imunisasi yang tidak lengkap, kekurangan vitamin $\mathrm{A}$, dan asupan MP-ASI yang tidak benar ${ }^{(1)}$

Menurut who tahun 2005 pnemonia adalah penyakit yang terletak pada saluran pernafasan dan angka kematian yang tercatat tinggi pada balita di dunia yaitu 19\% - 26\% . tahun 2007 di perkirakan sebanyak 1,8 juta kematian akibat pnemonia atau $9 \%$ pada kasus yang mencapai 9 juta kasus kematian. Dan berdasarkan data yang dimiliko oleh Riskesdas tahun 2007 di Indonesia pnemonia menjadi penyebab kematian balita setelah diare ${ }^{(2)}$.

Gejala klinis yang ditemukan pada pasien pneumonia pada anak juga didukung dengan pemeriksaan penunjang berupa darah lengkap, sputum dan foto rontgen thorax. Jika, hasil pemeriksaan penunjang telah dlakukan kemudia hasil tersebut dikumpulkan dan dianalisa serta dilakukan laoran agar data sesuai ${ }^{(3)}$.

Pada tahun 2017, cakupan penemuan kasus pnemonia pada balita relatif rendah dan mengalami penurunan tahun 2016. Diperkirakan terdapat 142.153 kasus pnemonia yang ditemukan pada tahun 2017, dimana 5,493 (3,86\%) diantaranya telah ditangani. Tahun 2016 jumlah kasus yang ditemukan sebanyak 280.620 , dengan jumlah kasus yang ditangani yaitu sebanyak 16.000 kasus $(5,7 \%){ }^{(4)}$.

Angka kematian pada balita yang disebabkan oleh pneumonia cukup tinggi di dunia. Terdapat $16 \%$ angka kematian pada anak yang berusia kurang dari 5 tahun berupa 920.136 balita, atau terdapat pada jumlah 2.500 setiap harinya, dan juga analisa data menyebutkan terdapat kematian 2 anak setiap menitnya di tahun 2015. Berdasarkan Data Riset Kesehatan Dasar Tahun 2018, didapatkan Prevalensi pneumonia meningkat dari 1,6\% menjadi $2 \%$ untuk di Indonesia ${ }^{(5)}$.

\section{METODE}

Desain penelitian studi kasus yang bersifat deskriptif dan retrospektif merupakan jenis desain yang digunakan dalam penelitian ini. Penelitian ini didasari oleh data rekam medis terkait gambaran diagnostik dan tatalaksana pasien penumonia anak rawat jalan Rumah Sakit Umum Daerah Dr. Pringadi Medan. Penelitian ini dilakukan di Rumah Sakit Umum Daerah Dr. Pringadi medan. Waktu Penelitian berlansung pada bulan maret 2020. Banyak sampel yang diperlukan minimal berjumlah 100 data rekam medis dari pasien anak Pnemonia rawat jalan di Rumah Sakit Umum Daerah Dr. Pringadi Medan. Metode Pengumpulan data yang digunakan yaitu dengan cara purposive sampling berupa rekam medis yang paling lengkap datanya. Analisa data menggunakan aplikasi Statiscal Product and Service Solition (SPSS) , data-data akan di analisis dengan statistik, distribusi proporsi dan akan dijelaskan dengan kalimat beserta gambar, tabel penjelasan data statistik dan proporsi.

\section{HASIL DAN PEMBAHASAN}

Penelitian ini dilaksanakan demi mengetahui gambaran diganosa dan tatalaksana pasien pneumonia anak rawat jalan Rumah Sakit Umum Daerah Dr. Pringadi Medan. Banyak sampel yang digunakan sebanyak 100 sampel dengan metode penelitian desain studi kasus deskriptif retrospektif yang diambil secara purposive sampling. Hasil penelitian ialah

Tabel 1. Distribusi Proporsi Pasien Pneumonia Anak Berdasarkan Umur di Rumah Sakit Umum Daerah dr. Pringadi Medan

\begin{tabular}{ccc}
\hline $\begin{array}{c}\text { Umur } \\
\text { (Tahun) }\end{array}$ & $\mathbf{F}$ & \% \\
\hline$<1$ & 37 & 37,0 \\
\hline $1-3$ & 25 & 25,0 \\
\hline $4-6$ & 17 & 17,0 \\
\hline$>6$ & 21 & 21,0 \\
\hline Total & $\mathbf{1 0 0}$ & $\mathbf{1 0 0 , 0}$ \\
\hline
\end{tabular}

Dapat dilihat dari penjelasan tabel diatas terdapat total terbanyak pasien Pnemonia anak di RSUD dr. Pringadi Medan berumur kurang dari 1 tahun yaitu sebanyak 37 anak $(37,0 \%)$ sedangkan jumlah pasien paling sedikit berumur 4 sampai 6 tahun yaitu sebanyak 17 anak (17,0\%).

Tabel 2. Distribusi Proporsi Pasien Pneumonia Anak Berdasarkan Jenis Kelamin di Rumah Sakit Umum Daerah dr. Pringadi Medan

\begin{tabular}{ccc}
\hline $\begin{array}{c}\text { Jenis } \\
\text { Kelamin }\end{array}$ & F & \% \\
\hline Laki - laki & 59 & 59,0 \\
\hline Perempuan & 41 & 41,0 \\
\hline Total & $\mathbf{1 0 0}$ & $\mathbf{1 0 0 , 0}$ \\
\hline
\end{tabular}

Dapat dilihat dari penjelasan tabel diatas terdapat total terbanyak pasien Pnemonia anak di RSUD dr. Pringadi Medan berjenis kelamin laki-laki 
Jurnal Ilmiah Mahasiswa Kesehatan Masyarakat Vol. 5/No. 3/Juli 2020; Issn: 2502-731X

yaitu sebanyak 59 anak (59,0\%) sedangkan jumlah pasien berjenis kelamin perempuan yaitu sebanyak 41 anak (41,0\%).

Tabel 3. Distribusi Proporsi Pasien Pneumonia Anak Berdasarkan Keluhan Utama di Rumah Sakit Umum Daerah dr. Pringadi Medan

\begin{tabular}{ccc}
\hline Keluhan Utama & F & \% \\
\hline Batuk & 6 & 6,0 \\
\hline Batuk berdahak & 3 & 3,0 \\
\hline $\begin{array}{c}\text { Batuk berdahak dan } \\
\text { sesak nafas }\end{array}$ & 45 & 45,0 \\
\hline Batuk dan sesak nafas & 42 & 42,0 \\
\hline Sesak & 4 & 4,0 \\
\hline Total & $\mathbf{1 0 0}$ & $\mathbf{1 0 0 , 0}$ \\
\hline
\end{tabular}

Berdasarkan tabel 3 di atas diketahui bahwa sebagian besar pasien Pneumonia anak di RSUD dr. Pringadi Medan memiliki keluhan utama yaitu batuk berdahak dan sesak nafas sebanyak 45 anak (45,0\%), sebanyak 42 anak (42,0\%) memiliki keluhan utama batuk dan sesak nafas, sebanyak 6 anak (6,0\%) memiliki keluhan utama batuk, sebanyak 4 anak $(4,0 \%)$ memiliki keluhan utama sesak, dan sebanyak 3 anak $(3,0 \%)$ memiliki keluhan utama batuk berdahak.

Tabel 4. Distribusi Proporsi Pasien Pneumonia Anak Berdasarkan Keluhan Tambahan di Rumah Sakit Umum Daerah dr. Pringadi Medan

\begin{tabular}{ccc}
\hline Keluhan Tambahan & $\mathbf{F}$ & $\mathbf{\%}$ \\
\hline Demam & 100 & 100,0 \\
\hline Total & $\mathbf{1 0 0}$ & $\mathbf{1 0 0 , 0}$ \\
\hline
\end{tabular}

Berdasarkan tabel 4 di atas diketahui bahwa seluruh pasien Pneumonia anak di RSUD dr. Pringadi Medan mengalami keluhan tambahan yaitu demam sebanyak 100 pasien $(100,0 \%)$.

Tabel 5. Distribusi Proporsi Pasien Pneumonia Anak Berdasarkan Pemeriksaan Fisik di Rumah Sakit Umum Daerah dr. Pringadi Medan

\begin{tabular}{ccc}
\hline Pemeriksaan Fisik & F & \% \\
\hline Auskultasi (Bronkial) & 22 & 22,0 \\
\hline Auskultasi (Ronhki Basah) & 39 & 39,0 \\
\hline $\begin{array}{c}\text { Perkusi (Redup), Auskultasi } \\
\text { (Bronkial) }\end{array}$ & 17 & 17,0 \\
\hline $\begin{array}{c}\text { Perkusi (Redup), Auskultasi } \\
\text { (Ronhki Basah) }\end{array}$ & 22 & 22,0 \\
\hline Total & $\mathbf{1 0 0}$ & $\mathbf{1 0 0 , 0}$ \\
\hline
\end{tabular}

Berdasarkan tabel 5 di atas diketahui proporsi pasien Pneumonia anak di RSUD dr.
Pringadi Medan berdasarkan pemeriksaan Fisik terbanyak yaitu pada ronkhi basah sebanyak 39 pasien anak (39,0\%), Temuan ini disebabkan oleh proses kerusakan selaput lendir bronkial akibat dari pelepasan respon inflamasi oleh sel T dan sel B, (6) sedangkan pemeriksaan Fisik terendah yaitu pada Perkusi (redup), Auskultasi (bronkial) sebanyak 17 pasien anak (17,0\%).

Tabel 6. Distribusi Proporsi Pasien Pneumonia Anak Berdasarkan Radiologi di Rumah Sakit Umum Daerah dr. Pringadi Medan

\begin{tabular}{ccc}
\hline Radiologi & F & \% \\
\hline- & 1 & 1,0 \\
\hline Infiltrat & 56 & 56,0 \\
\hline Infiltrat, Perkusi : redup & 3 & 3,0 \\
\hline Konsolidasi & 38 & 38,0 \\
\hline Konsolidasi, Perkusi : redup & 2 & 2,0 \\
\hline Total & $\mathbf{1 0 0}$ & $\mathbf{1 0 0 , 0}$ \\
\hline
\end{tabular}

Berdasarkan tabel 6 di atas diketahui proporsi pasien Pnemonia anak di RSUD dr. Pringadi Medan berdasarkan Radiologi adalah infiltrat sebanyak 56 pasien $(56,0 \%)$, infiltrat dengan perkusi (redup) sebanyak 3 pasien $(3,0 \%)$, konsolidasi sebanyak 38 pasien $(40,0 \%)$, konsolidasi dengan perkusi (redup) sebanyak 2 pasien (2,0\%) dan 1 pasien $(1,0 \%)$ tidak melakukan pemeriksaan radiologi.

Tabel 7. Distribusi Proporsi Pasien Pneumonia Anak Berdasarkan Pemeriksaan Lab di Rumah Sakit Umum Daerah dr. Pringadi Medan

\begin{tabular}{ccc}
\hline Pemeriksaan Lab & F & \% \\
\hline- & 54 & 54,0 \\
\hline $\begin{array}{c}\text { sputum: diplokokus gram + , } \\
\text { dan banyak }\end{array}$ & 10 & 10,0 \\
\hline $\begin{array}{c}\text { leukosit PMN Sputum: } \\
\text { diplokokus gram + }\end{array}$ & 36 & 36,0 \\
\hline Total & $\mathbf{1 0 0}$ & $\mathbf{1 0 0 , 0}$ \\
\hline
\end{tabular}
proporsi pasien Pnemonia anak di RSUD dr. Pringadi Medan berdasarkan pemeriksaan Laboratorium adalah Sputum : diplokokus gram + dan banyak leukosit PNM sebanyak 10 pasien $(10,0 \%)$ dan Sputum : diplokokus gram + sebanyak 36 pasien $(36,0 \%)$ sedangkan sisanya sebanyak 54 pasien $(54,0 \%)$ tidak melakukan pemeriksaan laboratorium. 

Vol. 5/No. 3/Juli 2020; Issn: 2502-731X

Tabel 8. Distribusi Proporsi Pasien Pneumonia Anak Berdasarkan Treatment di Rumah Sakit Umum Daerah dr. Pringadi Medan

\begin{tabular}{|c|c|c|}
\hline Treatment & $\mathbf{F}$ & $\%$ \\
\hline $\begin{array}{l}\text { Amoxilin sirup, } \\
\text { Ambroxol sirup, } \\
\text { Paracetamol sirup }\end{array}$ & 32 & 32,0 \\
\hline $\begin{array}{l}\text { Cefadroxil sirup, Ambroxol } \\
\text { sirup, Paracetamol sirup }\end{array}$ & 27 & 24,0 \\
\hline $\begin{array}{ll}\text { Cefadroxil } & \text { sirup, } \\
\text { Paracetamol sirup } & \\
\end{array}$ & 14 & 14,0 \\
\hline Cefotaxime injeksi & 2 & 2,0 \\
\hline $\begin{array}{ll}\text { Cefotaxime } & \text { injeksi, } \\
\text { Paracetamol sirup } & \\
\end{array}$ & 24 & 24,0 \\
\hline Paracetamol sirup & 1 & 1,0 \\
\hline Total & 100 & 100,0 \\
\hline
\end{tabular}

Berdasarkan tabel 8 di atas diketahui proporsi pasien Pnemonia anak di RSUD dr. Pringadi Medan berdasarkan treatment terbanyak adalah Amoxilin sirup, Ambroxol sirup, Paracetamol sirup yaitu diberikan kepada sebanyak 32 pasien $(32,0 \%)$, Pemberian amoxilin ini juga didukung oleh penelitian yang dilakukan oleh Agnes dimana ia mengungkapkan bahwa pemberian amoxilin merupakan pelihan utama terkait tingkat resistensi terhadap Cotrimoxazole yang tinggi (7), sedangkan treatment terendah yaitu pada parasetamol sirup yang diberikan kepada 1 pasien (1,0\%).

\section{PENUTUP}

Berdasarkan hasil penelitian, diperoleh kelompok umur yang paling banyak mengalami Pneumonia adalah pada umur masa bayi $(<1$ tahun) sebanyak $37 \%$, sedangkan kelompok umur terendah adalah umur 4 sampai 6 tahun sebanyak $17 \%$. Dari penelitian yang telah dilakukan didapatkan hasil yang serupa dengan penelitian yang dilakukan oleh Monita di RSUP DR.M. DJAMIL (2015) yang hasil penelitiannya terdapat dari 178 kasus pnemonia kelompok umur tertinggi adalah umur kurang dari 1 tahun sebanyak 78 pasien atau $43,8 \%{ }^{(8)}$.

Penelitian Kaunang di RSUP Prof. Dr,. R. D. Kandou manado (2015) juga sesuai pada penelitian yang telah dilakukan. Pada penelitian Kaunang (2015) diperoleh kelompok frekuensi tertinggi pnemonia pada anak terjadi pada kelompok umur masa bayi ( $<1$ tahun) sebanyak 108 pasien atau $68,4 \%$. Pada masa balita juga salah satu resiko tertinggi dapat terkena pneumonia. Anak berusia kurang dari 1 tahun lebih rentan terhadap penyakit pneumonia disebabkan sistem imunitas yang terdapat pada tubuh belum sempurna dan sistem saluran pernapasan yang cukup sempit dan masih dalam masa perkembangan ${ }^{(9)}$.

Berdasarkan hasil penelitian, data rekam medik rawat jalan anak dengan diagnosis utama pneumonia sebanyak 100 anak yang terdiri dari pasien anak dengan jenis kelamin Laki - laki sejumlah 59 anak dan jenis kelamin Perempuan sebanyak 41 anak. Dari penelitian yang telah dilakukan didapatkan hasil berupa pneumonia komunitas yang kasusnya paling banyak pada kelompok usia kurang dari 12 bulan 37\% dan urutan kedua pada usia anak kelopok usia 1 - 3 tahun dengan persentase $25 \%$ dan terendah pada rentang usia 4 - 6 tahun dengan persentase 17\% dikarenakan system imun yang sudah berkembang dengan baik.

Kenyataannya persentase yang didapatkan cendrung lebih banyak pasien anak laki- laki dibandingkan anak perempuan, hal ini berbanding lurus dengan penelitian Andriani Sari yang dilakukian di RS.PKU MUHAMMADIYAH YOGYAKARTA pada tahun 2014, pada penelitian Andriani Sari di jumpai bahwa anak laki - laki lebih banyak di jumpai di bandingkan anak perempuan, sekitar 87 pasien terdapat 50 anak laki - laki dan 37 anak perempuan. ${ }^{(10)}$.

Dari penelitian yang dilakukan, disimpulkan bahwa Pasien pneumonia anak paling banyak ditemukan pada penelitian di RSUD dr. Pringadi Medan adalah kelompok usia <12 bulan, dan cendrung didapatkan pada anak laki-laki dari ketimbang perempuan pada persentase angka 59\% banding $41 \%$.

Keluhan utama pasien pneumonia adalah batuk berdahak dan sesak nafas sebanyak 45 anak $(45,0 \%)$, sebanyak 42 anak $(42,0 \%)$ memiliki keluhan utama batuk dan sesak nafas, sebanyak 6 anak $(6,0 \%)$ memiliki keluhan utama batuk, sebanyak 4 anak (4,0\%) memiliki keluhan utama sesak, dan sebanyak 3 anak (3,0\%) memiliki keluhan utama batuk berdahak dan juga keseluruhan mengalami keluhan tambahan berupa demam (100\%). Pada pemeriksaan penunjang Laboratorium dengan hasil Sputum : diplokokus gram + dan banyak leukosit PNM sebanyak 10 pasien $(10,0 \%)$ dan Sputum : diplokokus gram + sebanyak 36 pasien $(36,0 \%)$ sedangkan sisanya sebanyak 54 pasien $(54,0 \%)$ tidak melakukan pemeriksaan laboratorium. Selain itu, biasanya anak dengan infeksi Pneumonia juga didapatkan penurunan kadar $\mathrm{Hb}$ dalam darah (Anemia). Komplikasi yang paling sering terjadi pada infeksi Pneumonia ini berupa ketidakseimbangan asam dan basa. Dan pada penatalaksanaan pemberian tindakan paling banyak adalah pemberian oral sebagai berikut Amoxicillin, 
Jurnal Ilmiah Mahasiswa Kesehatan Masyarakat Vol. 5/No. 3/Juli 2020; Issn: 2502-731X

Ambroxol, Cefadroxil dan Paracetamol dalam sediaan sirup dan injeksi Cefotaxime.

Penelitian yang telah dilakukan dan datadata yang telah didapat semoga kedapannya menjadi acuan untuk lebih baiknya penelitian tentang Pneumonia pada anak serta dapat mengembangkan potensi-potensi yang lebih tentang Pneumonia pada anak, serta lebih baiknya pemberian penatalaksanaan yang tepat pada pasien Pneumonia anak.

\section{DAFTAR PUSTAKA}

1. Airlangga $U$, Timur J. Hubungan antara pencemaran udara dalam ruang dengan kejadian pneumonia balita. 2014;392-403.

2. Cissy B Kartasasmita. pnemonia pembunuh balita. J Petrol [Internet]. 2013;369(1):1689-99. Tersedia pada: http://dx.doi.org/10.1016/j.jsames.2011.03.003 \%0Ahttps://doi.org/10.1016/j.gr.2017.08.001\%0 Ahttp://dx.doi.org/10.1016/j.precamres.2014.1 2.018\%0Ahttp://dx.doi.org/10.1016/j.precamres .2011.08.005\%0Ahttp://dx.doi.org/10.1080/002 06814.2014.902757\%0Ahttp://dx.

3. Handayani RP. Gambaran kegiatan penemuan kasus pneumonia pada balita di puskesmas sekota semarang tahun 2011. 2012;1:1-12.

4. Sumatera Utara profil kesehatan. Profil Kesehatan Sumut 2017. J Chem Inf Model. 2017;53(9):1689-99.

5. Kadek N, Srinadi A, Sutarga IM. Karakteristik Pengelola Program Pengendalian Penyakit Pneumonia Balita Di Puskesmas Se-Kabupaten Gianyar Pendahuluan Infeksi Saluran Pernapasan Akut ( Ispa ) merupakan infeksi yang terjadi pada setiap bagian dari sistem pernapasan mulai dari telinga tenga. 2020;7(1):11-9.

6. Brasers vl. Alterations of pulmonary fuction. In: pathophsysiologi the biologic basis for disease in adults and children. 2010. Hal. 1290-2.

7. Rahayu AS. Pneumonia pada Anak. J Biol Papua [Internet]. 2011;3(Vol 3, No 2 (2011)):82-8. Tersedia pada: http://ejournal.unicen.ac.id/index.php/JBP/artic le/view/49

8. Monita O, Yani FF, Lestari Y. Artikel Penelitian Profil Pasien Pneumonia Komunitas di Bagian Anak RSUP. J Kesehat Andalas. 2012;4(1):21826.

9. Kaunang $\mathrm{CT}$, Runtunuwu AL, Wahani AM. Gambaran karakteristik pneumonia pada anak yang dirawat di ruang perawatan intensif anak RSUP Prof. Dr. R. D. Kandou Manado periode 2013 - 2015. e-CliniC. 2016;4(2).

10. Sari A, Safitri I. Studi Penggunaan Antibiotik
Pasien Pneumonia Anak Di RS. PKU Muhammadiyah Yogyakarta Dengan Metode Defined Daily Dose (DDD). J Ilm Ibnu Sina. 2016;1(2):151-62. 